\title{
Multa curiosa Vallisneri's Early Studies on Earth Sciences
}

\author{
Francesco Luzzini \\ Università degli Studi del Piemonte Orientale, \\ Dipartimento di Studi Umanistici, Vercelli, Italy \\ francesco.luzzini@lett.unipmn.it
}

\begin{abstract}
In 1687, after he graduated in Medicine, young Antonio Vallisneri (1661-1730) returned in the Duchy of Modena and Reggio. In those years he mainly served as general practitioner; nevertheless, he also devoted many studies to various aspects of the natural sciences. He performed many observations, accurately reporting them in seven Quaderni, which were compiled between 1694 and 1701 .

Though the Earth sciences occupy only a small part of these diaries, the accuracy of the notes makes them a precious token of the scientific praxis adopted by the author in this field of study. This paper deals with the analysis of these early geological reports, pointing out the main criteria of Vallisneri's experimental method and paying attention to the great significance which these documents had in the elaboration of some of his published works.
\end{abstract}

Keywords

Vallisneri, Earth sciences, $17^{\text {th }}-18$ th centuries

The intellectual prestige achieved by Antonio Vallisneri in the eighteenth century European scientific community is by now well known. His contributions to the natural sciences cover a wide span of subjects ranging from medicine to entomology, from microscopy to botany. In this vast mass of disciplines the role played by Earth sciences is anything but secondary, though still partially elucidated.

With respect to geological topics, as in other branches of Vallisneri's research, a careful thought to the experimental practice was the dominant characteristic of his scientific work. This was not by chance, since Antonio's approach to natural philosophy was deeply rooted in his academic formation. In 1682, when he began to study medicine at Bologna University, the athenaeum was troubled by strife between two radically different epistemological traditions: on one side, the empirical medicine, whose leaders 
were the galenic physicians Giovanni Girolamo Sbaraglia (1641-1710) and Paolo Mini (1642-1693); on the other, Marcello Malpighi (1628-1694) supported the rationalist school, defending the validity of mechanism and corpuscolarism applied to anatomical studies. Vallisneri, being an earnest disciple of Malpighi, aligned himself with his master without hesitation; his stand, anyway, did not prevent him from absorbing from Sbaraglia's lectures the most valuable elements of empirical practice. ${ }^{1}$ This "contamination" resulted to be fruitful, since it allowed him to refine a particularly effective scientific praxis. In the case of Earth sciences, the outcome was a marked tendency to take into great consideration the existing relationship between two or more analyzed phenomena in the same environment, with a careful regard for agreement between theories and empirical data.

The first Earth sciences related notes in Vallisneri's documents date back to the last decade of the seventeenth century. In 1687, after he graduated, young Antonio returned in the Duchy of Modena and Reggio. There he served as general practitioner in Scandiano, Luzzara (since 1695) and Castelnuovo di sotto (since 1698). During these early years he employed most of his leisure time in the study of various sorts of natural phenomena: he performed many observations, methodically reporting them in seven diaries $^{2}$ (properly called by Dario Generali Quaderni di osservazioni). ${ }^{3}$ These documents are an incisive proof of the scientific versatility achieved by the author: in the Quaderni he proved his skill in different subjects like entomology, microscopy, botany and, of course, medicine. Though the Earth sciences occupy only a small part of these diaries, the accuracy of the notes makes them a precious token of the early experimental praxis adopted by Vallisneri in this field of study.

The earliest geological report is a concise note dated 24 February 1694, concerning a "fearful earthquake" that occurred in Mantua and Luzzara and that "was felt in all Europe" ("Towers fell, along with almost all the chimneys, and a lot of houses"). ${ }^{4}$ It was his own homeland, anyway, that

On this topic, see Dario Generali, Antonio Vallisneri. Gli anni della formazione e le prime ricerche (Firenze: Olschki, 2007), pp. 30-47.

2 Antonio Vallisneri, Quaderni di osservazioni, 7 vols. (Biblioteca Estense di Modena, Raccolta Campori, 701-707, $\gamma$. D. 6,36-42). The first and second Quaderno are now published in Antonio Vallisneri, Quaderni di osservazioni, Vol. 1, edited by Concetta Pennuto (Firenze: Olschki, 2004), Vol. 2, edited by Marco Bresadola (Firenze: Olschki, 2007).

3 See the Introduction by Dario Generali in Vallisneri, Quaderni di osservazioni, Vol. 1 (cit. note 2), p. VII.

${ }^{4}$ Vallisneri, Quaderni di osservazioni, Vol.1 (cit. note 2), p. 37. The noted event could have been a peripheral repercussion of the distant and far greater Val di Noto earthquake, that 
gave Vallisneri a fertile background for many cases of study. The hydrogeological, mineralogical and geomorphological features of the lower Po Plain acted as his first laboratory, where he set the basis for later researches. As for the case of the gypsum and sulphur veins discovered on Monte Gesso: a mountain located in the gypsum-sulphur formation typical of the northern borders of the Apennines. ${ }^{5}$

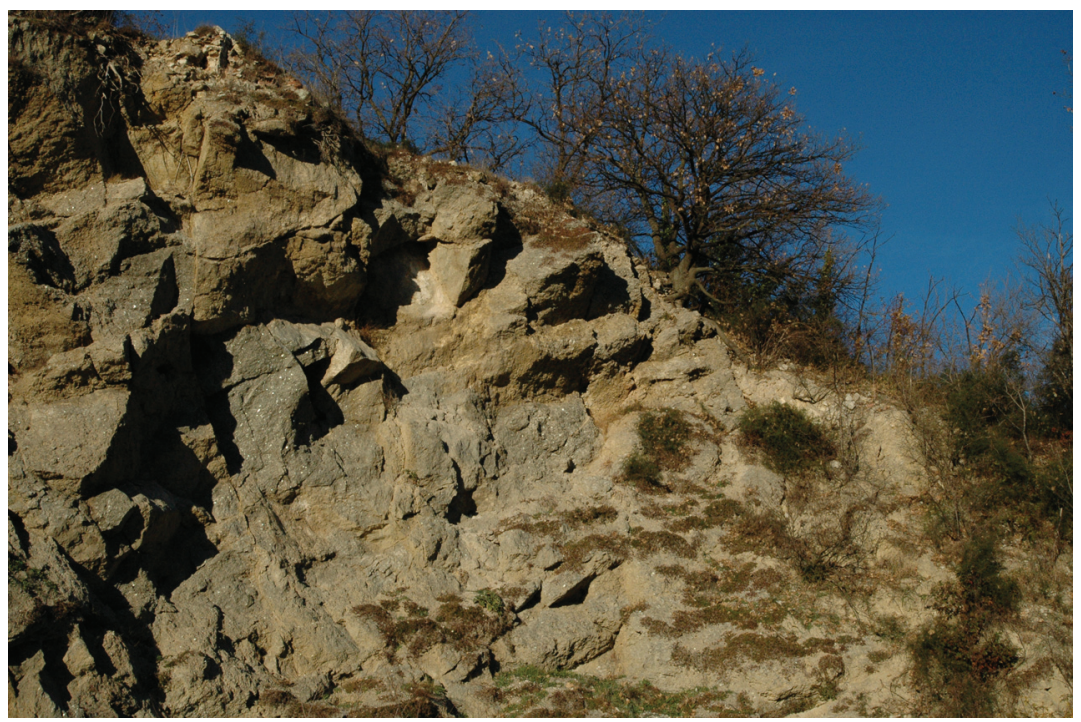

Figure 1. A gypsum outcrop on Monte Gesso (Albinea, Reggio Emilia, Italy). Picture by Stefano Meloni.

struck Sicily on 11 January 1693 . The main tremor occurred in the zone between Catania and Siracusa: it destroyed 45 towns and cities and caused more than 6o,00o fatalities. The seismic sequence lasted about two years, with a great number of repetitions (almost 15,000) also in northern Italy. On the chance that Vallisneri made a mistake in writing the year or that he used the calendar Ab Incarnatione Domini (according to which the year began on 25 March), the actual date could be 24 February 1695 . In this case the event could be exactly identified as the Santa Costanza earthquake. This tremor had its epicentre in Treviso and spread through northern Italy. This second hypothesis could be confirmed by historical records, since (with regard to Po Plain) there is no evidence of the event described by Vallisneri in 1694. See http://storing.ingv.it/cfti4med/.

${ }_{5}$ Gypsum $\left(\mathrm{CaSO}_{4} \cdot 2 \mathrm{H}_{2} \mathrm{O}\right)$ is a mineral usually found in evaporitic deposits, in association with sedimentary rocks. The gypsum layers of Monte Gesso are part of the gypsumsulphur formation typical of the northern Apennines, whose thick evaporitic strata result from the Messinian salinity crisis occurred in the late Miocene epoch (between 5.95 and 


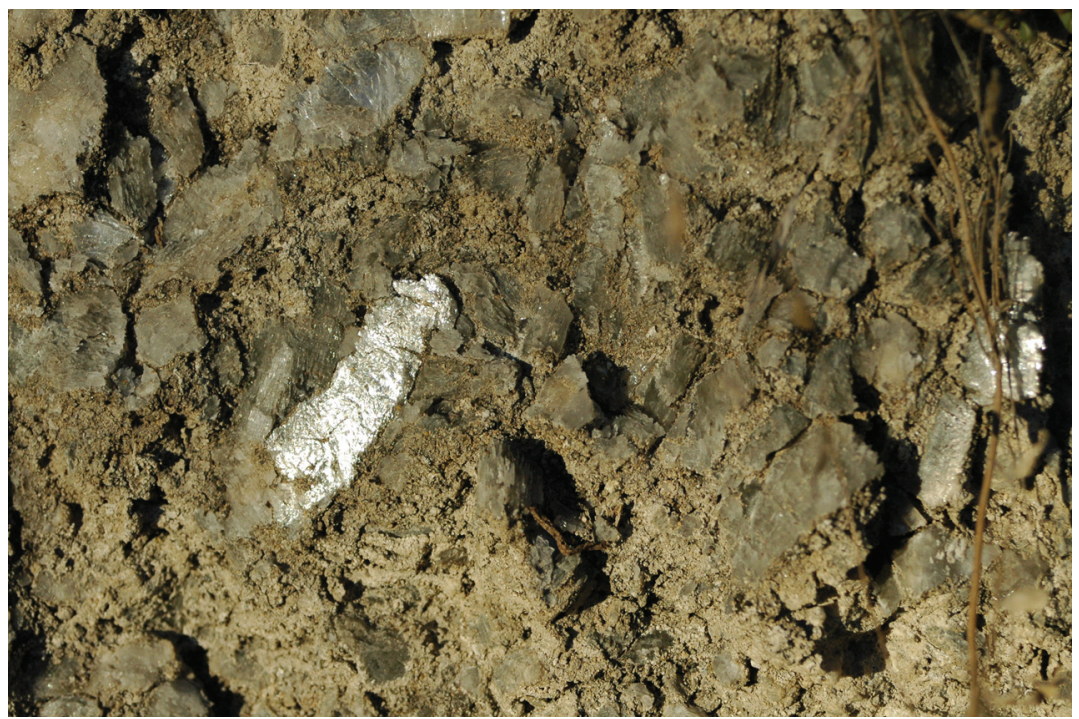

Figure 2. Gypsum crystals as they can be observed in the outcrop of Fig. 1. Picture by Stefano Meloni.

In a note dated 12 November 1691 Antonio reported the new finding:

It has been discovered in our Monte Gesso a new sulphur vein, that once tested has resulted to be of a greater perfection than the commonly sold kind. The Most Serene Prince ordered to bring here a certain Mr. Raggi from Romagna, in order to work and to discover the mine, but nothing has been revealed yet. ${ }^{6}$

5.33 million years before present). During this epoch occurred a temporary closure of the Strait of Gibraltar, that made the Mediterranean Sea desiccate almost completely. This event caused the formation of the evaporitic rocks that are now visible along the northern borders of the Apennines from Reggio Emilia to the Marche region. The sulphur (S) veins found in this zone result from the biochemical activity of bacteria. Under anaerobic conditions, sulphate reducing bacteria produce hydrogen sulphide gas $\left(\mathrm{H}_{2} \mathrm{~S}\right)$ from sulphate $\left(\mathrm{SO}_{4}\right)$ in gypsum. $\mathrm{H}_{2} \mathrm{~S}$ is then oxidized to elemental sulphur if exposed to oxygen. On these topics, see Pompeo Casati (ed.), Scienze della Terra, elementi di geologia generale (Milano: Città Studi Edizioni, 1996), pp. 518-519; Alfonso Bosellini, Storia geologica d'Italia. Gli ultimi 200 milioni di anni (Bologna: Zanichelli, 2005), pp. 66-67; Alfonso Bosellini, Emiliano Mutti, Franco Ricci Lucchi, Rocce e successioni sedimentarie (Torino: UTET, 1989), pp. 133-169; Eugene Odum, Basi di Ecologia (Padova: Piccin, 1988), pp. 30, 32, $110,162,484$.

${ }^{6}$ Vallisneri, Quaderni di osservazioni, Vol. 1 (cit. note 2), p. 35: "Si scoperse nel nostro Monte del Gesso novamente la vena del zolfo, quale provato è di perfezione maggiore di 
Vallisneri went on investigating the peculiar lithology of the Monte Gesso. He collected many specimens, also exploring some of the caves near to the mountain. In May 1694 he discovered in a cavern "a dark and chilly site", where he saw a spring whose "most clear and cool water" was "rejected by the beasts". He tasted it, and found it was extremely bitter. This peculiarity was to him a proof of the underground presence of gypsum:

The origin [of the bitterness] is not a mistery, being the mountain entirely made by gypsum. The spring likely passes between chalky stones, whose bitter particles soak in the water. Perhaps the underground heat or the sulphur itself calcined them, so that they are partially dissolved, and washed away by the flow. 7

Nearly seven months later, on 20 December 1694, the author explored another cavern near to the Borzano Castle. ${ }^{8}$ This detailed account is worth reporting here, as it contains many distinctive traits of Vallisneri's research praxis:

I went to Burzano in a cave near to the castle, inside which the water is heard falling from above straight into it. Once lit the lamp, the water is seen to fall down by big gypsum stones, and in one of them some steps are still visible of an ancient staircase, that went right to the end of the cavern to take water, which is frightening to see. In a side of the cavern there are still traces of a smoked oven, from which it is clear that the grotto was once inhabited. In two sites of the cave there are holes, and having thrown stones into them, they are heard falling after the water has fallen for a long time. I don't know where this water goes. At the bottom of the mountain there is a torrent that carries water, but it is very little if compared with the amount in the cave. Moreover, the villagers say that once an earthquake occurred, the water decreased, and that's because the ancients report that it was like a big channel, and indeed its capacity is still visible. This water that falls from above, and later hides, well supports Mr Bernardino Ramazzini's opinion on the origin of the water in the

quello, che ordinariamente si vende. Il serenissimo Principe Luigi mandò a pigliar un certo Raggi romagnolo, acciò lavorasse, e scoprisse la miniera, ma non s'è ancora scoperta”.

7 Vallisneri, Quaderni di osservazioni, Vol. 1 (cit. note 2), p. 42: “D'onde passi [il suo sapore amaro] non è difficile, perché essendo il monte tutto di gesso è probabile, che passi fra sassi di gesso, quale essendo amaro imprime nell'acqua il suo sapore rapendo seco sue particelle. Forse dal calor sotterraneo, o del zolfo, ch'ivi si trova, è questi in parte calcinato, e per ciò facile da esser sciolto, e portato dall'onde [...]"

8 This medieval castle is located near to the Monte Gesso. It was built on the top of a gypsum cliff. According to an archaeological excavation performed in 1999, its most ancient parts date back to the eighth century, in correspondence to the end of the Longobard Reign in Italy. 
springs of Modona, in his learned book ${ }^{9}$ De admiranda fontium Mutinensium origine. $^{10}$

In this text there is more than one interesting point. As in the previous note, it is possible to perceive an effort - characteristic of Vallisneri's scientific practice - in finding the links between the analyzed phenomena. To this custom he joined an accurate attention to the geological features of the environment, according to an experimental path that was substantially the same used some years later (and clearly outlined by him in 1726 in the "Supplementi al Giornale de' Letterati d'Italia")" in the exploration and description of the Apennines. ${ }^{12}$ By confronting the quantity of water in

9 Bernardino Ramazzini, De fontium Mutinensium admiranda scaturigine tractatus physico-hydrostaticus (Mutinae: Typis Haeredum Suliani Impressorum Ducalium, 1691), pp. 9-20, 21-29.

${ }_{10}$ Vallisneri, Quaderni di osservazioni, Vol. 1 (cit. note 2), pp. 34-35: "Mi portai a Burzano in una spelonca vicino al castello, dentro la quale si sente cadere dall'alto acqua nell'interna parte di quella a man diritta. Acceso il lume si vede precipitare giù per gran sassi di gesso, in uno de' quali sono ancora le poste d'una scala anticamente scolpitavi, che andava giù in fondo della caverna a prender acqua, cosa, che fa terrore. In una parte della caverna vi sono ancor le vestigie di un forno affumicato, dal che si vede essere stata una qualche volta abitata. In due lochi della caverna sono aperture, entro le quali gettati sassi, si sente, che cadono doppo longo cadere nell'acqua. Ove vada quest'acqua non si sa. In fondo del monte v'è un rivo, dal quale scaturisce una fonte, che porta acqua, ma è pochissima rispetto alla quantità della caverna. Anzi narrano i paesani, che doppo un terremoto si sminuì l'acqua, perché gli antichi narrano, che era, come un grosso canale, e in fatti vi si scorge la capacità. Quest'acqua cadente dall'alto, che poi si nasconde, molto bene favorisce l'opinione del Signor Bernardino Ramazzini circa alla generazione dell'acque delle fontane di Modona nel suo dotto libro De admiranda fontium Mutinensium origine."

${ }^{1}$ Antonio Vallisneri, "Continuazione dell'Estratto d'alcune Notizie intorno alla Garfagnana, cavate dal primo Viaggio Montano del Sig. Antonio Vallisnieri...", Supplementi al Giornale de' Letterati d'Italia, 1726, 3: 376-428, pp. 404-419.

${ }_{12}$ Antonio Vallisneri, Primi itineris per Montes specimen Physico-Medicum... (Archivio di Stato di Reggio Emilia, Archivio Vallisneri, 10, Scritti, minute e appunti scientifici e letterari d'Antonio Vallisneri sr., mazzo IV); Lezione Accademica intorno all'Origine delle Fontane, colle Annotazioni per chiarezza maggiore della medesima, di Antonio Vallisnieri, Pubblico Primario Professore di Medicina Teorica, e Presidente nell'Università di Padova. A Sua Eccellenza il Sig. Generale Co. Luigi-Ferdinando Marsilli (Venezia: Appresso Gio. Gabbriello Ertz, 1715); "Estratto d'alcune Notizie intorno alla Provincia della Garfagnana, cavate dal primo Viaggio Montano del Sig. Antonio Vallisnieri... dal Sig. Dottore Giovanbatista Perrucchini, e da lui indirizzato in una Lettera al Sig. Lodovico da Riva...," Supplementi al Giornale de' Letterati d'Italia, 1722, 2: 270-312; "Continuazione dell'Estratto d'alcune Notizie intorno alla Garfagnana, cavate dal primo Viaggio Montano del Sig. Antonio Vallisnieri..." (cit. note 11). On this topic, see Francesco Luzzini, "La Tana che urla: cenni di speleologia vallisneriana," in Antonio Vallisneri. La figura, il contesto, le immagini storiografiche, edited by Dario Generali (Firenze: Olschki, 2008), pp. 349-369; "Cavità naturali ed artificiali in 
the cavern with the lesser amount flowing out from the little torrent at the bottom of the mountain, the author came to suppose the existence of some hidden, underground streams that carried the lacking water on the surface. This system, in which "water [...] falls from above, and later hides", is typical of karst (and gypsum karst) aquifers. ${ }^{13}$ In Antonio's opinion, it well supported the theory outlined by Bernardino Ramazzini (1633-1714) in his treatise on the origin of the springs in Modena: this statement proves that Vallisneri, since the beginning of his scientific activity, well knew the $D e$ fontium Mutinensium. The mentioned "cave near to the castle" can be easily identified as the renowned Tana della Mussina in Borzano: this grotto has a great archaeological importance, given that an Eneolithic sepulchral site has been discovered in it in the second half of the nineteenth century. ${ }^{14}$ The author's mention to the "traces of a smoked oven", therefore, could refer to the residual signs of the Eneolithic funeral rituals. These data are definitely significant, as they confirm that the first cave explorations (along with the first analytical descriptions) in this part of Italy were performed in historical age by Vallisneri, and not by Lazzaro Spallanzani (1729-1799) or Serafino Calindri (1733-1811), as it has recently been thought. ${ }^{15}$

Garfagnana e Lunigiana. Le esplorazioni di Antonio Vallisneri," in Antonio Vallisneri dalla Garfagnana alla Scienza (Lucca: Maria Pacini Fazzi Editore, 2010), pp. 93-124; Ezio Vaccari, "Le istruzioni per i geologi viaggiatori in Toscana e in Europa tra Settecento e Ottocento," in Viaggi e Scienza, le istruzioni scientifiche per i viaggiatori nei secoli XVII-XIX, edited by Maurizio Bossi, Claudio Greppi (Firenze: Olschki, 2005), p. 11.

${ }^{13}$ In the karst and gypsum karst areas the easy dissolution of soluble bedrock causes the presence of many sink points. On the contrary, the exit points are few, as the torrents tend to converge downstream in a single river. When a stream emerges on the surface at the base of the karst system, it is called a reappearing spring. See Bernard Collignon, Manuale di Speleologia (Bologna: Zanichelli, 1992), pp. 27, 67-68.

${ }_{14}$ The Eneolithic, or Chalcolithic, was a transitional period between the Neolithic and the Bronze Age. In the Emilia region it spanned roughly from 3300 to 2300 BC. In this lapse of time it occurred a partial passage from the use of stone tools to early copper tools.

The first excavations in the Tana della Mussina were carried out in 1872 by Abbot Gaetano Chierici (1819-1886). In this cave were found many stone tools and animal bones, along with the human remains of 18 individuals, some with combustion marks on them. In conformity with the most reliable theory, the cavern was used as a burial site: during the rites, probably, the corpses were partially burned. On this topic, see Stefano Benazzi, Giorgio Gruppioni, "Testimonianze antropiche pre-protostoriche in aree gessose," in Le aree carsiche gessose d'Italia, edited by Giuliana Madonia, Paolo Forti (Bologna: Istituto Italiano di Speleologia, 2003); James Tirabassi, I misteri della grotta (Reggio Emilia: Musei Civici, 2005).

${ }_{15}$ Michele Sivelli, "La speleologia nei gessi d'Italia: un percorso storico," in Le aree carsiche gessose d'Italia (cit. note 14). 
According to the Quaderni, 1694 was for Antonio a very profitable year as regards the Earth sciences. On 8 May the diaries report the description of one of the strangest and most intriguing natural phenomena ever studied by him: the so-called salse. ${ }^{16}$

The author devoted considerable efforts to dealing with the problem of the origin of these curious, little volcanoes (that at the end of the seventeenth century were much more active than now) ${ }^{17}$ He payed

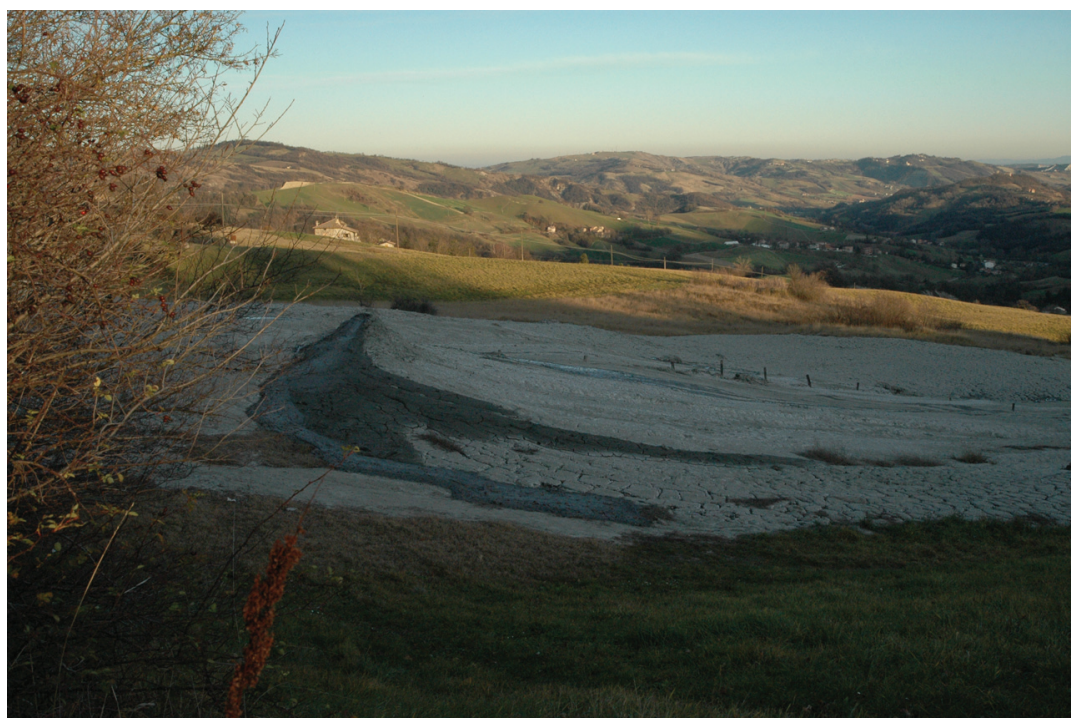

Figure 3. A salsa in all its extension (Regnano-Viano, Reggio Emilia, Italy). Once the mud has reached the surface, it dries near to the crater and accumulate, therefore forming little mud volcanoes a few meters tall (on the left). Picture by Stefano Meloni.

${ }^{16}$ A salsa is a peculiar phenomenon of secondary volcanism. It is a cold, muddy mixture composed of water, clay, carbon dioxide and hydrocarbons (usually methane) that leaks out from the ground. The term "salsa" means "salty", as the mixture contains NaCl. Its salinity is equivalent to $1 / 2-1 / 3$ of seawater. On this topic, see http://www.comune.viano.re.it.

${ }_{17}$ The last two considerable emissions happened in 1915 (this one lasted for 15 days) and in 1932. Anyway, it seems that at the end of the eighteenth century violent eruptions still occurred. These phenomena were accompanied by the size enlargement of craters and by vertical fissures in the ground. In one of the most violent episodes, which was accurately described by the physician Domenico Gentili (1744-1825) in 1796, the mud mass collapsed at the end of the eruption and caused a landslide in the fields beneath it. In recent years the mud volcanoes entered a phase of relative dormancy: the portion of land covered with mud, therefore, has decreased in extent. During an excursion in Querciola, made in 2007 


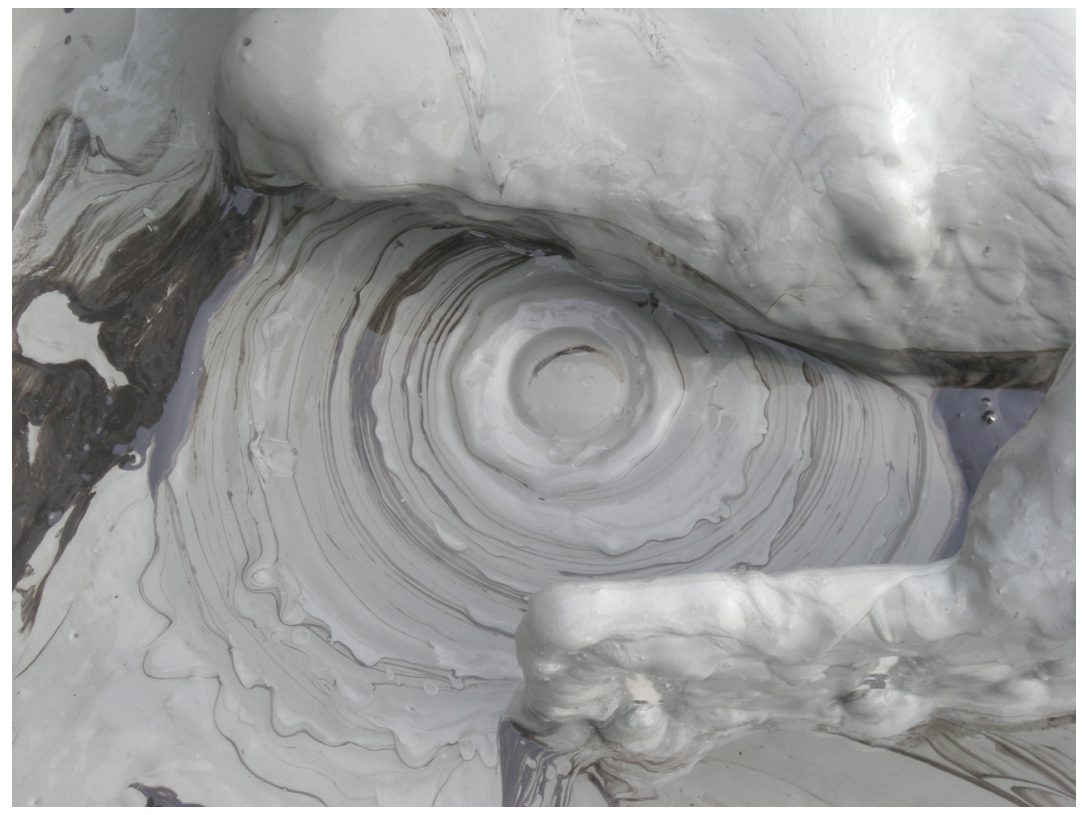

Figure 4. The salsa in a crater (Regnano-Viano, Reggio Emilia, Italy). The gas leak from the surface is caused by slow and constant movements of the Earth's crust: these trigger the underground sacks in which the mixture is enclosed to open or to compress. The mud volcanoes grow in height if the mud leak is faster than water erosion; oppositely, they tend to decline.

special attention to the ones in Querciola, located in the territory of Regnano: ${ }^{18}$

I went to see the salsa in Querzola. It boiled in two points, like a pot on the fire, and sometimes it sprayed mud in the air. During the boiling an ash colored clay continuously gushes, dripping down from the mountain and reaching a stream at its bottom. Once thrown stones where the boilings were, they sinked in the depth. Not far from the site of the boilings are two springs of crystal

by the author of this article with Dario Generali, Stefano Meloni and Oscar Poli, only some small gas leaks have been noticed in the main craters; these resulted in the formation of small bubbles on the surface. As a matter of fact, in the last years the eruptions were sporadic and not comparable to the ancient ones. On this topic, see Domenico Gentili, "Osservazioni fatte dal Dottore Domenico Gentili sulla salsa di Querzuola e segnatamente sull'eruzione del 22 aprile 1796," in Notizie biografiche, e letterarie degli scrittori dello Stato Estense, Vol. 1 (Reggio Emilia: Tipografia Torreggiani e Compagno, 1833), pp. 275-283; http:// www.comune.viano.re.it.

${ }_{18}$ This territory is now part of Viano (RE). 
clear water, and as those [the boilings] change place, so does the water. The villagers say that when [the volcano] angers (and the roar, or rumbling, is clearly heard from Scandiano), it erupts clay and stones as high as towers, and sparks, and lights are visible by night. In the past it [the salsa] was very little, and barely known, now it is huge, and it takes up a great part of the mountain. Sometimes it erupted clay and stones over a house as far from it as a pistol shot, and one day they [the people in the house] had to flee, since the soil trembled, and bellowed, so that the house cracked in some points. About half a mile from it, there is a lesser one, but it doesn't boil anymore. The mud that it vomits is very effective to desiccate tumours, mainly those on the legs. In humid times, and when the weather turns from good to bad, it boils, and rumbles more than usual, and from Scandiano it seems a thunder, when it is darker and farther, and it easily deceives us. ${ }^{19}$

Once more, in this study the observed phenomenon is not disconnected from its natural context. As for this case, a link was detected between the point where the springs "of crystal clear water" arose and the position of the boiling craters. ${ }^{20}$ The careful annotation of the villagers' testimony is not a marginal additional information: rather, it responds to a well defined epistemological conception of experimental science. As a fierce defender of empiricism, Vallisneri always sustained the value of direct experience in the study of nature. The folk's reports, if verified by further observations, were as valid as the accounts made by any other eye witness.

The author often insisted on this point in his later works. He did not despise the use of the "popular" "rough, natural philosophy" as a sort of

${ }_{19}$ Vallisneri, Quaderni di osservazioni, Vol. 1 (cit. note 2), pp. 40-41: "Fui a vedere la salsa di Querzola. Questa in due lochi bolliva, come pentola al foco, e di quando in quando gettava all'aria spruzzi di fango. Nel bollire esce sempre terra di color cinerizio, che cola giù per lo monte, ed arriva sino a un rivo in fondo di quello. Gettativi sassi, ovve erano que' bollori, sprofondavano in abisso. Poco lungi dal sito de' bollori vi sono due sorgenti d'acqua limpida, e cristallina, e mutando loco quelli, ancor l'acqua muta loco. Narrano i paesani, che quando s'infuria (e si sente da Scandiano chiaramente il boato, o rimbombo) getta all'alto, come torri, la terra co' sassi, e di notte tempo si vedono framezzo sprizzi di faville, e di luce. Anticamente era piccolissima, e appena cognita, ora è grandissima, ed occupa di spazio un buon tratto del monte. Alle volte ha spruzzata terra, e sassi sin sopra una casa lungi un tiro di pistola, ed una volta fra l'altre furono necessitati a fuggire, tremando, e muggendo il suolo, di modo, che la casa in varii lochi sdrucì. Lungi un mezzo miglio ve n'è un'altra più piccola, ma più non bolle. Quella terra, che vomita fuori è bonissima per esiccare i tumori particolarmente delle gambe. Ne' tempi umidi, e quando il tempo vuol far mutazione di buono in cattivo, bolle, e romoreggia più del solito, e a noi da Scandiano rassembra il tuono, quando è più cupo, e lontano, e facilmente inganna."

${ }^{20}$ This fact could have been caused by the interaction of underground sacks of gas with the clay layers near to them. The pressure exerted by leaking methane could have activated some stream drift, thus shifting the points where the springs upraised. 
rhetorical weapon against those "renowned philosophers" who "only look after speculations, sitting on a bench", ${ }^{21}$ in a provocative attempt to show the efficacy of the experimental method against its detractors (and their use of the principle of authority). On the other side of the coin, in many cases Vallisneri did not hesitate to quote the works of the authors whose theories supported his thought. ${ }^{22}$ An evident inconsistency between the former statement and the latter cannot be ignored: nonetheless, even in this case the coherence of Antonio's empiricism was untouched, since he justified his trust in the referred scholars on the basis of the experimental demonstrability of their theories. Besides, such a conduct was common among contemporaneous scientific authors, being it considered a useful rhetorical instrument to strengthen oneself's opinion in a treatise. ${ }^{23}$

In the Quaderni there is almost no trace of rhetorical or polemical expressions. In Vallisneri's intention, these manuscripts were intended to be the "laboratory papers" from which he could take material for future publications. ${ }^{24}$ Despite the heterogeneous disciplines that are covered in these documents, there is no clear separation between subjects: the own Earth sciences notes contain many links to other topics as biology or medicine. A good example is the note on the salse, whose mud was "very effective to desiccate tumours". The same is for the case of a report dated (once more) 8 May 1694, describing a strange "sulphuric spring" where the cattle used to drink "with no harm done". ${ }^{25}$ The medical significance of these observations was further developed in 1711, when the author took part in

${ }^{21}$ Vallisneri, Lezione Accademica intorno all'Origine delle Fontane (cit. note 12), p. 41. Quite obviously, the author (who by 1715 was a well-renowned physician and one of the most powerful lecturers at the University of Padua) did not mean to put common people and philosophers on the same level. He simply intended to point out the need for empiricism in the study of natural phenomena.

${ }^{22}$ A clear example is in Vallisneri, Lezione Accademica intorno all'Origine delle Fontane (cit. note 12), p. 23 .

${ }_{23}$ On the smart editorial strategy adopted by Vallisneri and on the rhetorical skill that he used in his published works, see Dario Generali, "Il testo tra comunicazione scientifica e strategie editoriali. Il caso di Antonio Vallisneri", in Edizioni e traduzioni di testi filosofici, Esperienze di lavoro e riflessioni, edited by Marialuisa Baldi, Barbara Faes de Mottoni (Milano: Franco Angeli, 2006); Antonio Vallisneri. Gli anni della formazione e le prime ricerche (cit. note 1), pp. 383-411.

${ }^{24}$ It is the case of Antonio Vallisneri, "Saggio de' Dialoghi sopra la curiosa origine di molti Insetti del Medico Filosofo Antonio Valsinieri da Scandiano," La Galleria di Minerva, 1696, 1: 297-322; "Secondo Dialogo di Antonio Valsinieri Scandianese, Cittadino di Reggio sopra la curiosa Origine di molti Insetti," La Galleria di Minerva, 1700, 3: 297-318, 353-372. On this topic, see Dario Generali's introduction in Vallisneri, Quaderni di osservazioni, Vol. 1 (cit. note 2), pp. VII-XXII.

${ }^{25}$ Vallisneri, Quaderni di osservazioni, Vol. 1 (cit. note 2), p. 41. 
the new edition of the De Thermis: ${ }^{26}$ a medical essay written by the Roman physician and philosopher Andrea Bacci (1524-160o). In this treatise, that examined the therapeutic effects of thermal waters, Valliseri enclosed an appendix written by him, the title of which was De nova Methodo Thermarum explorandarum. ${ }^{27}$ Not a few of the observations reported in this edited text came from the Quaderni, without exception for the several notes on the "sulphuric spring", on the "bitter water" that was found under the Monte Gesso, and on the salse. ${ }^{28}$

The longest account related to the Earth sciences that can be found in the first Quaderno is dated December 1694. It is an exhaustive report of the many experiments that the author performed on some fragments of "petrified coal"29 that he found in the river Tresinaro: ${ }^{30}$

The petrified coal, without those particles of stone that are seen in it, sinks immediately, unlike the unpetrified one.

Having mixed the coal with stone and having ground them as powder, I spilled vitriolic spirit ${ }^{31}$ on it, and this [powder] boiled, and gave out bubbles. It did not boil with sal armoniac..$^{2}$

It burns very easily, it fumes a lot, and it smells very awful.

${ }^{26}$ Andrea Bacci, De Thermis Andreae Baccii Elpidiani, medici, atque philosophi, civis Romani, libri septem (Venetiis: Apud Vincentium Valgrisium, 1571).

${ }_{27}$ Antonio Vallisneri, "De nova Methodo Thermarum explorandarum, mineraque, et viribus Multorum Fontium, quos Bacciu complexus non est," in Andrea Bacci, De Thermis Andreae Baccii Elpidiani, Civis Romani, Medici, atque Philosophi, Libri Septem... Editio novissima, quae in singulis libris tractentur, versa pagina indicabit (Patavii: Sumptibus Jo. Baptistae Conzatti, 1711), pp. 287-365.

${ }_{28}$ See also Generali, Antonio Vallisneri. Gli anni della formazione e le prime ricerche (cit. note 1$)$, p. 129 .

${ }^{29}$ Fossil coal. It derives from the build-up and sedimentation of organic matter (almost exclusively from plants) in an anoxic environment. The increase in thickness of the organic layers leads to a gradual increase in temperature and pressure. These conditions cause the ejection of volatile matter and water from the layers, along with the increase in carbon percentage. This process occurs gradually: it starts from the lower sedimentary strata and passes through different phases. Depending on the carbon percentage, this matter is called (from less to more) peat, lignite, sub-bituminous coal, bituminous coal, anthracite.

The most favorable environment for the genesis of coal seams is the lagoon, both coastal or in a river delta. The Po Plain was originally a lagoon that evolved in a wetland; however, since this zone is still geologically young, exploitable coal reserves have not formed yet. The "petrified coal" found and analyzed by Vallisneri, therefore, was probably a sort of lignite or low-carbon coal. See Chris Pellant, Rocce e minerali (Milano: R.C.S. Libri, 1995), pp. 244-245.

${ }^{30}$ The river Tresinaro flows in the Province of Reggio Emilia. It is a tributary of the river Secchia. It originates in Felina (Castelnovo ne' Monti, RE) and flows from southwest to northeast, reaching Scandiano.

${ }^{31}$ Sulphuric acid $\left(\mathrm{H}_{2} \mathrm{SO}_{4}\right)$. Scientific note by Andrea Castellani. See Vallisneri, Quaderni di osservazioni, Vol. 1 (cit. note 2), p. $5^{2}$.

$3^{2}$ Ammonium chloride $\left(\mathrm{NH}_{4} \mathrm{Cl}\right)$. Scientific note by Andrea Castellani. See Ibid. 
It could be suspected that it is pine coal, or it comes from another wood which has not been well consumed. A piece of coal striped with stone, that weighed XII, and gr. ${ }^{33} \mathrm{XIIII}$, once burnt weighed gr. XXXX.

Some pure coal without stripes, that weighed 31, [once burnt] weighed gr. XXI. Try what remains of the ordinary coal.

Having thrown into water some pieces of the above mentioned petrified coal while they were in red heat, they floated somewhat, then sank. The ordinary coal did the same, and it sank too.

Having made some other pieces cold, they constantly floated, as ordinary coal does.

The smell of petrified stone is different from that of naval pitch, the latter being more pleasant, and almost comforting, while the former is very bad, and offensive.

Once lit, the naval pitch looks slightly like the above mentioned coal, but the flame tends to be white, and its smoke is not evil smelling, as I said. They say there is also a kind that, if burned, liquefies, but not this coal, nor the ordinary coal.

The ordinary coal, which is called strong, does not raise flames, but just very little sparks stick out from it, and slowly it is burnt to ashes.

Using a burning glass the coal does not rise flames, but throws very gentle sparks, and where the rays hit, it collapses, and turns into ashes.

Having placed our coal on flaming coals and blowing them with a bellows, it began to smoke greatly, then burnt with a cloudy and smoky flame. Once burnt it soils, where it did not soil before, as ordinary coal does.

Once thrown into water, the ordinary coals harden, and do not soil as before. Try it in cloudy and saltpetre water. ${ }^{34}$

The ordinary coal, when it is burned once more, in dying is burnt to ashes inside, but our coal is not burnt to ashes, except on the surface; it remains coal inside. The former and the latter are similar, that is light. Etc.

Cook in water the above mentioned coals, and also see if there is something floating at the top [of the water].

The well ground coal sinks when it is soaked. Fabricius, lib. 2 De halitu, Physica, ${ }^{35}$ tract. VI, pag. $264 \cdot{ }^{36}$

33 Grains (unit of measurement of mass).

34 Water with potassium nitrate $\left(\mathrm{KNO}_{3}\right)$.

35 Honore Fabri, Physica, id est, Scientia rerum corporearum, Tomus tertius, continens tractatum V et VI... Nunc primum in lucem prodit (Lugduni: Sumptibus Laurentii Anisson, 1670), tract. VI, lib. II, prop. IV, Ex terra pura nullus halitus educi potest.

${ }^{36}$ Vallisneri, Quaderni di osservazioni, Vol. 1 (cit. note 2), pp. 52-53: "Il carbone impietrito solo senza que' ramenti di pietra, che si vedono, subito va al fondo a diferenza del non impietrito. Gettato spirito di vetriolo sopra il carbone rimescolato con pietra e macinato impalpabile, bollì molto, e sollevossi in bolle. Non bollì collo spirito di sal armoniaco. Abbrugia benissimo, fuma molto, e mena un odore fetido. Può sospettarsi, che sia carbone di pino non ben padito, o di altro legno.

Un pezzo di carbone colle strisce di sasso inframezzo, che pesava XII, e gr. XIIII, abbrugiato restò gr. XXXX. 
As it frequently happens in science history, the greatest value of this document does not reside in the scientific conclusion outlined by the author after having reported the experiment, but in the experiment itself. In this emblematic case, the extreme accuracy of the account makes possible to study in a very detailed fashion the analysis criteria used by Vallisneri. A first, basic sequence of tests concerned the perceptual characteristics of the observed matter: color, smell, texture. ${ }^{37}$ The samples were then exposed to different substances, from water up to salts and corrosive agents (as the sulphuric acid). The combustion of the specimens provided further data: this procedure was probably the last to be performed, since it implied the destruction of the samples. The experiments were carried out using a comparative method, by testing known analogous substances (as "ordinary coal" and "naval pitch") and confronting them with the main case. Indeed, a difference existed, as the combustion of the "petrified coal" resulted to be imperfect and caused a lot of "evil smelling smoke"..$^{8}$

Carbone schietto senza strisce, che era 31, restò gr. XXI.

Provare, che cosa resta il carbone ordinario.

Gettati in aqua pezzetti del carbone sudetto impietrito rosseggianti di foco, ed accesi stettero alquanto a galla, poi piomborono al fondo. Il simile fece il carbone commune, e andò anch'egli al fondo. Lasciati raffreddare altri pezzetti stettero sempre a galla, come fa il carbone ordinario. L'odore del carbone impietrito è diferente da quello della pece navale, essendo quello della pece più grato, e quasi confortativo, e l'altro noiosissimo, ed offensivo. La pece navale nell'accendersi ha qualche simiglianza col carbone sudetto, ma la fiamma è più bianchiccia, ed il suo fumo non è fetente, come ho detto. V'è anche dicono, che nell'abbruggiarsi appoco appoco si liquefà, ma il carbone nulla, come pure il carbone ordinario. Il carbone ordinario detto forte non leva fiamma, ma solo da lui si spiccano minutissime faville, e a mano a mano s'incenerisce. Collo specchio ustorio il nostro carbone non leva fiamma, ma getta gentilissimi sprizzi di faville, e resta affossato il loco, ove ferirono i raggi, e diviso in cenere. Posto il carbon nostro sopra carboni accesi stuccicati dal soffietto incominciò fortemente a fumicare, poi ad ardere a fiamma torbida, ed affumata. Abbrugiato una volta tinge poi, come fa il carbone ordinario, dove prima non tingeva. I carboni ordinari gettati in acqua via più se indurano, e non tingono così bene. Provare in acqua torbida, e nitrata.

Il carbone ordinario, quando novamente si roventa, nell'estinguersi s'incenerisce sino nel centro, ma il carbone nostro non s'incenerisce, se non alquanto nella superficie, e internamente resta carbone. L'uno, e l'altro poi è simile, cioè leggiero. Etc.

Cuocere in acqua i sudetti carboni, e veder pure, se in cima nuota qualche cosa. Il carbone ben trito, ed inzuppato d'umore va al fondo. Fabricius, lib. 2 De halitu, Physica, tract. VI, pag. 264."

37 Sometimes, as in the cases of the salse and the bitter spring under the Monte Gesso, the own flavour of the substances was tested.

${ }^{38}$ A strong smoke emission from burning coal indicates a considerable presence of water and impurities in the sample. These data seem to confirm the assumption that the "petrified coal" found by Vallisneri in the Tresinaro was essentially composed of peat or lignite, since these substances are richer in water and volatiles if compared with older types, as bituminous coal or anthracite. See Pellant, Rocce e minerali (cit. note 29), pp. 244-245. 
As it happened to many other reports contained in the Quaderni, even this last note was eventually published. Antonio inserted it in an heterogenous article entitled Estratto di notizie sopra la famosa Erba Fumana, ${ }^{39}$ in the third volume of the journal "La Galleria di Minerva". The Estratto began with a botanical topic. It concerned the therapeutic properties of the famous erba fumana, a subshrub that was quite common on the slopes of the Emilian Apennines..$^{40}$ This plant was, however, linked to a geological subject, having been mentioned by Francesco Ariosto (1430-1499) in his $D e$ oleo montis Zibinii: a manuscript (then published) ${ }^{41}$ that dealt with the natural hydrocarbon emissions in the zone of Nirano (Modena). The entire second part of the Estratto was devoted to exposing the many tests performed by Vallisneri on the coal of the Tresinaro. In this report Antonio's list of experiments was enriched by another precious element: the microscopic observation, by means of which the author could assert that in the coal

[...] he did not see those many pores that the most inquisitive Hooke ${ }^{42}$ observed in the ordinary coal, the number of which is so great, and prodigious, que dans un rang long de la 18 partie d'un poulce en a contè jusq'a 150. D'où il conclud que dans un charbon d'un poulce de diametre il n'y on doit pas avoir moins de cinque millions sept cent vingt quatre mille. Journal des Scavans an. MDCLXVI. 6og. ${ }^{43}$ He just observed that it was full of many roughnesses, and in some parts it was freckled with stony grains. ${ }^{44}$

39 Antonio Vallisneri, "Estratto di notizie... sopra la famosa Erba Fumana...," La Galleria di Minerva, 1700, 3: 105-108.

${ }^{40}$ Fumana procumbens (Ordo Malvales, Familia Cistaceae). The Family Cistaceae counts about 200 species, mostly subshrubs, typical of the temperate areas. The Genus Fumana is common in arid and stony habitats of the Mediterranean basin and of sub-mountanious zones, as, for instance, the land called magredi in the Region of Friuli-Venezia Giulia and the Apennines near Modena. As Vallisneri wrote in the Estratto, this plant was believed to have astringent and vulnerary properties. In Helianthemum nummularium, that belongs to the same family of Fumana, the same medical properties come from a particular glycoside, tannins, resins, salicylic acid and $\mathrm{Ca}$ and $\mathrm{K}$ salts that are present in its leaves. Anyway, the presence of these substances in Fumana procumbens is not verified. See on this topic Paola Gastaldo, Compendio della flora officinale italiana (Padova: Piccin, 1987), pp. 222-223.

${ }^{41}$ Francesco Ariosto, Francisci Ariosti De oleo montis Zibinii seu Petroleo agri Mutinensis libellus e manuscriptis membranis editus ab Olig. Jacobaeo (Hafniae: Literis reg. maj. \& univ. typogr. Joh. Phil. Bockenhoffer, 169o).

${ }^{42}$ Robert Hooke (1635-1703).

43 "Micrographia: or some physiological descriptions of minute bodies made by magnifying glasses" (anonymous review), Journal des Sçavans, 1666, 42: 738-749, p. 748.

${ }_{44}$ Vallisneri, "Estratto di notizie... sopra la famosa Erba Fumana..." (cit. note 39), p. 107: “[...] non vide quella quantità di pori, che osservò nell'ordinario carbone il curiosissimo 
Anyway, to Vallisneri these differences were not such as to consider the samples unfit to be admitted into the group of "fossil coals". Rather, while the coal from Tresinaro was richer in "stony juice", the ordinary one had much more "bitumen" in it, therefore burning easily and without ejecting impurities in the meanwhile. After all (and he once more appealed to the rhetorical instrument of "reliable authority") the own "always laudable" Daniel Sennert (1572-1637) stated that "alius autem plus bituminis, alius plus succi lapidescentis habet; unde et alius flammam facile concipit, alius nonnisi aliis carbonibus adhibitis, et follibus inflammatur". ${ }^{45}$

The Estratto was addressed to Diacinto Cestoni (1637-1718), an apothecary from Leghorn. This peculiar character, who kept an assiduous correspondence ${ }^{46}$ with Vallisneri until his death, seemed to embody the superiority claim of experimentalism over speculative philosophy. Despite the lack of academic training, his innate intellectual curiosity and his vast and heterogeneous scientific experience allowed him to earn a firstrate competence in the natural sciences. In many cases this resulted to be equal - and, with regard to the pure experimental practice, often superior - to the skill possessed by several academic authors. Dario Generali has clearly pointed out the crucial role played by Cestoni in shaping Vallisneri's experimental praxis and thought. ${ }^{47}$ This "great

Hook, il numero de' quali è sì grande, e prodigioso, que dans un rang long de la 18 partie d'un poulce en a contè jusq'a 15o. D'où il conclud que dans un charbon d'un poulce de diametre il n'y on doit pas avoir moins de cinque millions sept cent vingt quatre mille. Journal des Scavans an. MDCLXVI. 6og. L'osservò solo pieno di molte scabrezze, e seminato in alcuni luoghi di micolini di pietra". On the role played by microscopy in Vallisneri's scientific practice, see Generali, Antonio Vallisneri. Gli anni della formazione e le prime ricerche (cit. note 1), pp. 271307; "L'uso del microscopio in Vallisneri," in From Makers to Users. Microscopes, Markets, and Scientific Practices in the Seventeenth and Eighteenth Centuries, edited by Dario Generali, Marc Ratcliff (Firenze: Olschki, 2007), pp. 231-270.; Francesco Luzzini, "Antonio Vallisneri e la questione dei vermicelli spermatici: un'indagine storico-naturalistica," in From Makers to Users (cit. note 44), pp. 73-89.

45 Vallisneri, "Estratto di notizie... sopra la famosa Erba Fumana..." (cit. note 39), p. 108. The quotation is from Daniel Sennert, Epitome scientiae naturalis (Wittenberg: 1618). It was located in Daniel Sennert, Danielis Sennerti Opera Omnia in Quatuor Tomos divisa, Tomus primus (Lugduni: Sumptibus Ioannis Antonii Huguetan \& Marci Antonii Ravaud, 1656), p. 53 .

${ }^{46}$ See at this regard Diacinto Cestoni, Epistolario ad Antonio Vallisneri, edited by Silvestro Baglioni, 2 vols., Vol. 1 (Roma: Reale Accademia d'Italia, 1940); Vol. 2 (Roma: Reale Accademia d'Italia, 1941).

47 Dario Generali, "Uno speziale che "superava la sua condizione." Il caso dell'invisibilità postuma di Diacinto Cestoni”, in Figure dell'invisibilità. Le scienze della vita nell'Italia d'Antico Regime, edited by Maria Teresa Monti, Marc J. Ratcliff (Firenze: Olschki, 2004), 
man", ${ }^{48}$ who had correspondence with Marcello Malpighi and Francesco Redi (1626-1697), was regarded with great esteem by Antonio. From 1697 to 1718 (well after he became a lecturer at the University of Padua) he exchanged letters with Cestoni almost once a week, sometimes sending and receiving natural samples. ${ }^{49}$ This custom was apparent proof of an advantageous cooperation between the two scientists, that ranged from sharing information and naturalistic experiences to laboratory practices, and covered multiple interests as biology, medicine, microscopy and Earth sciences as well. With respect to this last case, Cestoni's influence on his friend showed maximum effectiveness in a particular and troublesome theme: the research on the origin of freshwater.

Vallisneri's opinion on this topic was fully developed and expressed in 1715, in his treatise Lezione Accademica intorno all'Origine delle Fontane.

Anyway, many pieces of information contained in some previous manuscript notes and published works ${ }^{5^{0}}$ make clear that since the last decade of the seventeenth century he was deeply interested in the study of springs. The dominant theory in those years found its roots in the Cartesian assumption of alembics: it considered the freshwater as originated from the sea after a process of filtration through rock layers. Renowned scholars and naturalists as Luigi Ferdinando Marsili $\left(165^{8-1730}\right)^{5^{1}}$ and Bernardino

pp. 83-118.; Antonio Vallisneri. Gli anni della formazione e le prime ricerche (cit. note 1), pp. 319-350.

${ }^{48}$ Antonio Vallisneri, Epistolario, 2 vols., Vol. 1: 1679-1710, edited by Dario Generali (Milano: Franco Angeli, 1991), p. 178.

49 Generali, Antonio Vallisneri. Gli anni della formazione e le prime ricerche (cit. note 1), pp. 323-325.

$5^{0}$ Vallisneri, Primi itineris per Montes specimen Physico-Medicum (cit. note 12); "Estratto di Fisico-Mediche novità...," La Galleria di Minerva, 1706, 5: 283-285; "Fontana d'Acqua limpida, che tigne i Panni in nero su i Monti di Modana", in Prima Raccolta d'Osservazioni, e d'Esperienze... (Venezia: Appresso Girolamo Albrizzi, 1710), pp. 205-206; "Viaggio per i Monti di Modena...," in Prima Raccolta d'Osservazioni, e d'Esperienze... (cit. note 50), pp. 245-267; "De nova Methodo Thermarum explorandarum" (cit. note 27), pp. 352-360; "Del Bagno a acqua nelle colline di Pisa di Vibio Rustigalli. 1638," Giornale de' Letterati d'Italia, 1712, 11: 192-204; "Stato presente della Salsa di Sassuolo...," Giornale de' Letterati d'Italia, 1713, 13: 154-202; Quaderni di osservazioni, Vol. 1 (cit. note 2), pp. 34-35.

${ }^{51}$ Luigi Ferdinando Marsili, Histoire physique de la mer. Ouvrage enrichi de figures dessinées d'après le Naturel. Par Louis Ferdinand Comte de Marsilli, membre de l'Academie Royale des Sciences de Paris (Amsterdam: Aux dépens de la Compagnie, 1725), p. 13; "Osservazioni fisiche intorno al Lago di Garda, detto anticamente Benaco," in Scritti inediti, (Bologna: Zanichelli, 1930), p. 57. See also Vallisneri, Epistolario, Vol. 1 (cit. note 48), pp. 283-284; Ezio Vaccari, "Luigi Ferdinando Marsili geologo: dalle miniere ungheresi alle Alpi svizzere," 


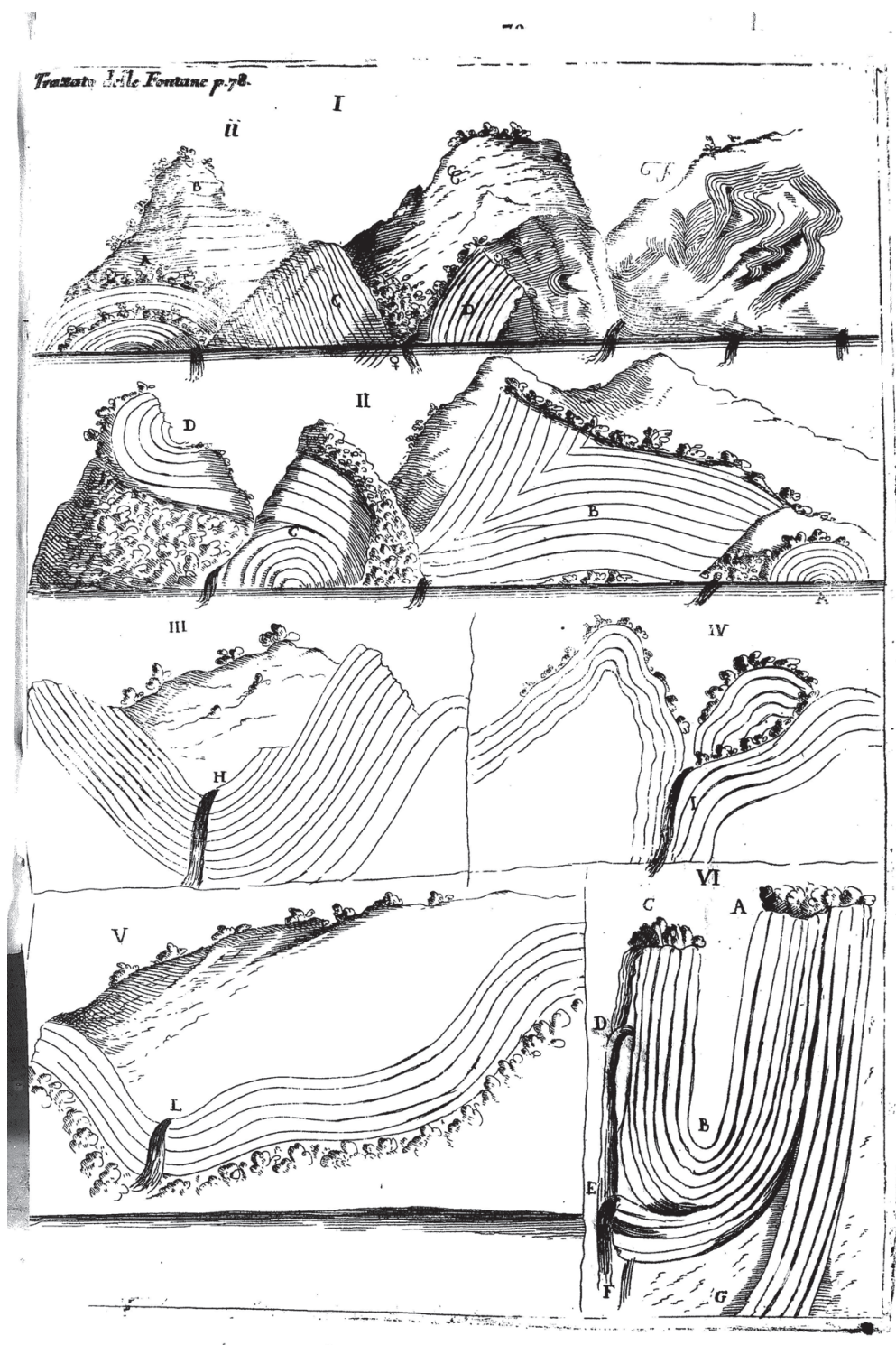

Figure 5. A plate from the Lezione Accademica intorno all'Origine delle Fontane (1715). This plate, describing various folds and strata of the Alps of Switzerland and Tirol, was illustrated by Johann Scheuchzer (1684-1738), brother of the renowned naturalist Johann Jakob (1672-1733). 
Ramazzini ${ }^{2}$ partially supported this supposition, since they judged that the meteoric water alone was not enough to replenish rivers, springs and groundwater supplies. In contrast with them, Vallisneri firmly opposed the alembics theory, persuaded as he was that all the freshwater came from rain or from the melting of glaciers on the mountains. He justified his belief by asserting that the rock strata were simply unable to convert salt water into freshwater, as he proved by experimental means and as his "faithful, and honest friend Mr Cestoni"53 affirmed. Indeed, the apothecary's role in this matter was decisive, as the correspondence attests. ${ }^{54}$ Eighteen years before the publishing of the Lezione Accademica, in a letter to Vallisneri dated 2 December 1697 , he firmly argued that

$[\ldots]$ it is clear that the salt water of all universe cannot be made fresh and drinkable by filtration, whatever its proportion. My profession is an unerring teacher in this regard, and I know for sure that salt water has to be distilled in order to be converted into freshwater: and in all universe this job is perpetually carried out by the heat from the sun and from the air, and through the rains it [the water] comes down again: therefore, the rains are surely the nourishment for the springs and rivers of this world. 55

These words show beyond any ambiguity Cestoni's opinion. They probably had a great effect on Vallisneri, given that they came from a preeminent experimentalist. Yet, the author expressed his desire to verify in first person the truth. He made this by performing what can be considered his most fanciful, and probably one of his best documented experiments in the field of Earth sciences. As he wrote in the fifth Quaderno in 1698,

It occurred to me to do this experience, in order to see if the springs of the mountains, of the valleys, and of other places come from the sea or from

in Four Centuries of the Word Geology, Ulisse Aldrovandi 1603 in Bologna, edited by Gian Battista Vai, William Cavazza (Bologna: Minerva Edizioni, 2003), pp. 179-186.

${ }^{52}$ Ramazzini, De fontium Mutinensium (cit. note 9), pp. 9-30.

53 Vallisneri, Lezione Accademica intorno all'Origine delle Fontane (cit. note 12), p. 22.

54 For a detailed report of this case, see Generali, Antonio Vallisneri. Gli anni della formazione e le prime ricerche (cit. note 1), pp. 326-331.

55 Cestoni, Epistolario ad Antonio Vallisneri, Vol. 1 (cit. note 46), p. 84: “[...] chiara cosa è, che l'acqua salata di tutto l'universo non è possibile ridurla dolce, e bevibile per via di filtrazione, intendo di qual si sia porzione. La mia professione è maestra infallibile di tal dottrina, e so di certo, che a voler ridurre dolce l'acqua salata, è necessario distillarla: e questo lavoro del distillare lo fa incessantemente il calor solare, et aereo in tutto l'universo, e poi per via di pioggie torna a venir di nuovo a basso: sicché asseverantemente le pioggie sono l'alimento delle fontane, e fiumi di questo mondo." 
rainwater, in fact they say that once thrown a well sealed pot into the sea, the water that soaks in through the pores of the pot becomes fresh, leaving the salt outside. Thus, I ordered to make a ball with pottery clay, and having put it into water, the water took eight days to penetrate, since I ordered to fire it in the kiln for a long time. Having broken the ball, I found that the salt water soaked in with no loss of salt. ${ }^{6}$

Immediately Vallisneri wrote to "Mr Cestoni in Leghorn", so that his friend could repeat the same test. Cestoni threw into the sea a vase made of "a raw sort of clay" that he tied to a lace. He opened it after fifteen days, and found salt water inside. ${ }^{57}$ The two autonomous experiments proved the theory of alembics wrong: the springs did not originate from the sea, but from the rains ("and in the Arabian deserts, where it never rains, no spring can be found"). Moreover, it was clear that "the seawater becomes fresh only by distillation, and not by filtering".$^{8}$

The "pottery test" was extremely effective in its simplicity. The result of this experiment became a central feature of the Lezione Accademica, along with the many other pieces of information collected by the author during his journeys in the Apennines. ${ }^{59}$ Nevertheless, as expected, the bare facts alone would not have been enough to let Vallisneri's theories prevail on rival ones in an academic context. Another ingredient was needed: namely, a well-defined theoretical framework that - together with a significant rhetorical ability - could make these facts persuasive to the distinguished audience of the Republic of Letters. It was therefore not by chance that in the treatise of 1715 the simple experimental data were integrated with a precise theoretical system, that was deeply influenced by the Leibnizian doctrines of scala naturae and of the recognition of divine providence in nature. This tendency was characteristic of Vallisneri's mature

$5^{5}$ Vallisneri, Quaderni di osservazioni, Vol. 5 (cit. note 2), c. 42r: "Mi saltò in capo di fare questa esperienza per vedere, se le fontane de' monti, delle valli, ed altri luoghi vengano dal mare, o se dall'acque piovane, perché dicono, che gittata una pentola ben chiusa in mare l'acqua, che dentro penetra per i pori della pentola resta dolce, lasciando al di fuori la salsedine. Feci dunque fare una palla vuota di terra da pignatte, e messa nell'acqua, tardò otto giorni a trapellar l'acqua, perché l'aveo fatta ben cuocere nella fornace. Rotta la palla trovai l'acqua salsa penetrata senza perdere il sale."

57 As Generali noticed, Cestoni claimed in his letters to have been the first to perform this experiment. See Generali, Antonio Vallisneri. Gli anni della formazione e le prime ricerche (cit. note 1), pp. 328-330.

${ }_{5}^{8}$ Vallisneri, Quaderni di osservazioni, Vol. 5 (cit. note 2), c. 42v.

59 On this topic, see Luzzini, "La Tana che urla: cenni di speleologia vallisneriana" (cit. note 12); "Cavità naturali ed artificiali in Garfagnana e Lunigiana. Le esplorazioni di Antonio Vallisneri” (cit. note 12). 
works. ${ }^{60}$ From this point of view Antonio diverged from the strict empiricism professed by Cestoni, given the efforts he made to join experimental science and philosophical elaboration. Anyway, it is undisputed that solid experimentalism always remained the core of his research. The Quaderni, with their methodical and vivid notes and with their anxious marginalia, are perhaps the most eloquent proof of this stance.

${ }^{60}$ See Dario Generali, “Antonio Vallisneri corrispondente leibniziano," in Rapporti di scienziati europei con lo Studio bolognese fra '6oo e '7oo, edited by Marta Cavazza (Bologna: Presso l'Istituto per la Storia dell'Università, 1987), pp. 125-140; "Storia e storiografia della scienza," in Franco Andrietti, Dario Generali, Storia e storiografia della scienza. Il caso della sistematica (Milano: Franco Angeli, 2002), pp. 70-72; Francesco Luzzini, "Flood conceptions in Vallisneri's thought," in Geology and Religion: A History of Harmony and Hostility, edited by Martina Kölbl-Ebert (London: Geological Society, 2009), pp. 77-81. 